\title{
Coordination and health sector adaptation to climate change in the Vietnamese Mekong Delta
}

\author{
Daniel Gilfillan $^{1}$, Thu T. Nguyen ${ }^{2}$ and $\underline{H a}$ T. Pham $^{3}$
}

\begin{abstract}
This research examines the impact of three coordination dimensions on health sector adaptation to climate change in the Vietnamese Mekong Delta: cross-scale, cross-sectoral, and cross-boundary. While tasks are divided up between government ministries and departments in Vietnam, there is little collaboration on issues that span mandates. Similarly, while water flows in the Vietnamese Mekong Delta take resource management and health concerns across provincial boundaries, formal mechanisms for interprovincial collaboration are lacking. While decentralization efforts have sought to devolve authority and decision making to lower levels, there is continued state-centered top-down policy making, and this limits collaborative coordination across scales. All three of these issues inhibit health sector adaptation to climate change in the Vietnamese Mekong Delta, and though these coordination issues are recognized by the Vietnamese government, to date there has been little success in addressing them. The authors hope to stimulate further debate and discussion of coordination problems, and conclude that despite some significant challenges, the South West Steering Committee could play a facilitating role coordinating climate change responses in health and other sectors across the Vietnamese Mekong Delta. As an analysis of governance, this research is applicable to other areas and sectors in Vietnam, as well as to other parts of South East Asia.
\end{abstract}

Key Words: adaptation; climate change; cross-boundary coordination; cross-scale coordination; cross-sectoral coordination; health; Mekong Delta

\section{INTRODUCTION}

As a result of climate change, precipitation patterns are already changing and impacting on freshwater availability (WHO 2015), which has both direct and indirect impacts on human health (Costello et al. 2011). As examples, changing precipitation patterns can directly impact the spread of infectious disease, and more intense rainfall combined with outdated storm-water drainage systems can lead to higher levels of vector- and waterborne diseases (e.g., USFS 2011, Rasul 2014). Christopoulos et al. (2012:310) described the importance of different sectors collaborating to develop "tailor-made solutions" that "can provide local traction and address [both] socio-economic and environmental tensions.” Across scales, the IPCC (2014a) noted that national government coordination of subnational adaptation efforts through mechanisms such as policies and legal frameworks as well as financial support and provision of information enhances planning and implementation of adaptation measures. Similarly limited governance coordination is observed to undermine adaptation efforts (Haines-Young and Potschin 2008; see also Cash et al. 2006). Coordination between local government and higher levels of government can also assist with coordination between local administrative areas, reducing development and planning conflicts (Baker et al. 2012). For Vietnam, cross-scale, cross-sectoral, and cross-boundary coordination issues are of particular importance because human health in developing countries is likely to be more severely impacted by climate change than in other parts of the world (Lesnikowski et al. 2013), and climate change impacts in the Vietnamese Mekong Delta, for example, are expected to be particularly severe (Tran et al. 2015).

This paper is written to stimulate debate about the importance of coordination between sectors, between provinces, and between scales to support health sector adaptation to climate change. The paper builds on theoretical contributions that argue the importance of coordination for adapting to climate change, and proposes a possible longer term solution to improve health sector adaptation in the Vietnamese Mekong Delta that addresses all three coordination dimensions. In this paper, adaptation to climate change, in human societies, means to either "exploit beneficial opportunities," or "moderate harm" that is brought about by a changing climate (IPCC 2014b:118). Coordination refers to both the distribution of tasks among actors and collaborative action of two or more actors to achieve agreed goals. The former of these is referred to in this paper as functional cooperation, and the latter as collaborative cooperation. The three dimensions of coordination examined in this research are summarised in Table 1.

Within Vietnam it is important to clarify the nature of coordination. Although Vietnamese government documents such as Vietnam's Intended Nationally Determined Contribution (INDC), for example, acknowledge the need for more effective coordination between ministries and localities, there is no clear description of what effective coordination means (e.g., GOV 2015a).

This research has wide-reaching implications, with a review of INDCs and national communications to the UNFCCC from South East Asian countries indicating that Vietnam has been the most proactive country in the region in terms of developing adaptation policies, strategies, and plans including sectoral adaptation strategies at the national level, and provincial level adaptation plans. This makes Vietnam policy making a model from which other countries may choose to learn, both for the positive aspects and to help them avoid some of the challenges that Vietnam has faced.

The research was informed by systems theory and resilience thinking. Systems theory is premised on the idea that systems have 
Table 1. Three dimensions of coordination.

\begin{tabular}{lll}
\hline \hline Dimension of Coordination & Description & Examples in Literature \\
\hline Cross-scale & $\begin{array}{l}\text { Interactions between government mechanisms at different } \\
\text { levels, for example between the national and provincial levels. }\end{array}$ & $\begin{array}{l}\text { (Cash et al. 2006, Haines-Young and Potschin 2008, } \\
\text { IPCC 2014a) } \\
\text { Cross-boundary }\end{array}$ \\
$\begin{array}{l}\text { Interactions that occur between administratively and/or } \\
\text { politically distinct places to deal with environmental issues } \\
\text { such as climate change impacts. }\end{array}$ & $\begin{array}{l}\text { Interactions between government sectors such as health and al. 2012, Nguyen 2012) } \\
\text { environment }\end{array}$ & (USFS 2011, Christopoulos et al. 2012) \\
Cross-sectoral & & \\
\hline
\end{tabular}

distinct boundaries that insulate them from external influences. In relation to governance, systems theory consists of factors such as feedback loops and communication and control mechanisms, as well as allowing for changes in governance paradigms: for example, moving from centrally controlled governments to governance through a variety of techniques and instruments (see Esmark 2011). Resilience thinking is geared toward adaptability to continuously changing circumstances, rather than trying to achieve an ideal and static end state. In other words resilience is the "capacity to change in order to maintain the same identity" (Folke et al. 2010). To date, responding to environmental changes and challenges in the Vietnamese Mekong Delta has been weighted toward infrastructure construction and other hard responses that lack this flexibility (Garschagen 2010, Garschagen and Kraas 2011), whereas resilience approaches are suited to sustainably responding to a continuously changing climate. The combination of resilience thinking and systems theory in this research reflects changes currently taking place in Vietnamese governance as well as further changes that could better facilitate health sector adaptation to climate change.

\section{LITERATURE REVIEW}

\section{Health and climate change}

In the 2014 Intergovernmental Panel on Climate Change (IPCC) report, Smith et al. (2014) reported that human health will be sensitive to changes in temperature and precipitation, including through droughts, floods, and heatwaves made worse by climate change. In addition to resultant direct health effects, there will be indirect human health effects resulting from crop failures, changing patterns of disease, and population displacement, highlighting the cross-sectoral nature of climate change impacts. The difficulties in responding to these impacts is magnified where there is a lack of policy coordination across sectors (e.g., Huang et al.2011). For countries that have poor infrastructure, high levels of poverty and inequality, as well as significant public health challenges, health resources will be particularly strained by climate change impacts (e.g., Lesnikowski et al. 2013), and the impacts of climate change are expected to further disadvantage poor and marginalized populations (e.g., Marmot 2007). A further cross-sectoral impact is that health challenges also inhibit economic development because there are direct economic costs in treatment and indirect costs because ill workers are less productive (e.g., Smith et al. 2014; see also Gerdham and Ekam 2005 for links between environmental determinants, human health, and household-level economic outcomes).

The Mekong Delta is expected to be severely affected by climate change impacts (Tran et al. 2015), however vulnerability is a function both of physical impacts and the ability of affected populations to adapt (Yusuf and Francisco 2009). The population of the Vietnamese Mekong Delta is predominantly rurally based, with many people living in poverty and having low levels of education (e.g., McElwee 2010). This makes the population of the delta highly vulnerable to the increasing frequency of typhoons and frequent flooding of low-lying coastal areas that are associated with climate change (as well as to the resultant increase in vector-, water-, and food-borne diseases; McElwee 2010; see also McMichael et al. 2003 and Gamble et al. 2016 for descriptions of cross-sectoral climate change impacts on human health). Increased hospitalizations for diarrhoeal diseases in the Vietnamese Mekong Delta are already associated with periods of high temperature, humidity, and peaks in rainfall (Phung et al. 2015), and diseases related to frequent heat waves such as respiratory infections are also increasing in the region (Benedikter 2014). Other regional analyses also highlight links between a warmer, more variable climate, and adverse health effects, which will impact the poor most significantly, particularly women and children (Mackay and Russell 2011).

\section{Adaptation across boundaries, scales, and sectors}

Adaptation can happen in a variety of ways and at a range of scales, and is often motivated by extreme events and increased climate variability rather than by long-term trends (Bierbaum et al. 2013). At the most local level, adaptations to climate change tend to be coping measures that cost little. More expensive longer term adaptation planning at the local level is less likely to occur autonomously without incentives from national governments or the private sector (Porter et al. 2014), and, in the case of developing countries, international adaptation financing. This highlights the importance of cross-scale coordination, and there is recognition in the literature that good cross-scale governance links support climate change adaptation, with decisions required at global, national, regional, and local levels (e.g., Armitage 2008, Termeer et al. 2010). Termeer et al. (2010) argued that there are costs of coordinating across scales, but despite these costs, Cash et al. (2006) observed that recognizing issues at different scales enables easier identification of problems, and hence pathways to resolve them. The cross-scale processes involved in managing environment and health in the Vietnamese Mekong Delta make cross-scale governance an important concern (see Tai 2015 for arguments on the importance of cross-scale governance dynamics).

Vietnam has made commitments under the United Nations Framework Convention on Climate Change (UNFCCC; for examples see Table 2), and although communications to the 
UNFCCC are not directly implementable as policies, they link to the development of national policies, strategies, and plans. Nationally, Vietnam has a variety of overarching climate change policies such as the National Target Program to Respond to Climate Change (NTP-RCC), as well as sectoral plans that incorporate climate change considerations. Although national governments provide support such as policy frameworks, the subnational scale plays a fundamental role in ensuring adaptation actions are tailored to local circumstances (Snover et al. 2007, UNDP 2007). Similarly, Galarraga et al. (2009) argued that subnational organizations can make significant contributions because their greater awareness of local conditions combined with greater flexibility allow them to take decisive, targeted actions in response to climate change (see also Parkes et al. 2010).

In line with these arguments, and under requirements of the NTPRCC, each province in Vietnam has developed its own climate change adaptation action plan. Despite this, in the Vietnamese Mekong Delta, provincial adaptation plans do not pay adequate attention to cross-boundary cooperation, even where doing so could support longer term economic growth and sustainable development (Truong 2011, Nguyen 2012). Baker et al. (2012) noted the importance of coordination between local government areas in Queensland, Australia, to help prevent conflicts as adaptation policies are developed and implemented. In Vietnam, administrative boundaries between provinces combined with a lack of regional level databases, which would provide the scientific foundation for action as well as academic research, have constrained adaptation to climate change across the Vietnamese Mekong Delta (Nguyen 2012, Tran et al. 2015).

One factor that continues to influence cross-scale governance dynamics in Vietnam is the decentralization program, which forms a part of Vietnam's Doi Moi reforms (United Cities and Local Governments 2009). The Doi Moi reforms were instituted by the Government of Vietnam, beginning in 1981, to transition from a centrally planned to a market-based economy (Irvin 1995). The decentralization process was accelerated in the year 2000, when the Vietnamese National Assembly resolved to transfer responsibilities from central to local governments wherever possible (Fritzen 2006). The World Bank (2015) reported that fiscal decentralization has been successful, but Vu(2012) observed that the decentralization reforms are not meeting government expectations, and described a top-down decentralization in Vietnam, with government functions devolved on the basis of tasks for which higher levels of government should not be responsible. In contrast, bottom-up decentralization requires higher level government to take responsibility for tasks or functions that lower levels are not equipped to fulfil. Vu (2012) argued further that Vietnam lacks some of the fundamental prerequisites for successful decentralization, such as transparency and accountability, resourcing of provinces, as well as uneven distribution of fiscal, political, and administrative decentralization. Christoplos et al. (2017) and Garschagen (2016) both noted the paradox of central government attempts to empower subnational levels while at the same time retaining tight overall policy control. Garschagen (2016) emphasized these tensions relative to national development and Christoplos et al. (2017) discussed the importance of local level participation and ownership over adaptation to climate change. Achieving local ownership could be difficult however, given Benedikter's (2016) observation of persistent rigidity of state planning and budgeting processes combined with top-down resource allocation. Similarly, Gainsborough et al. (2009) noted top-down, state-centered policy making, which is also evident through Hansson's (2003) description of the government's strained relationship with civil society. Likewise, Benedikter (2014) observed that large-scale operations in Vietnam tend to exclude local government agencies and communities. The central government's desire to retain tight control undermines cross-scale coordination efforts, including for health sector adaptation to climate change.

Further to the above observations, both Thayer (1995) and Fforde (2011) observed a lack of political change in Vietnam's decentralization. Compounding this systemic rigidity is MacLean's (2013) argument that bureaucratic self-interest has led to a "paper-based" reality in government documentation that does not reflect on-the-ground reality. Although the government is active in developing and adopting policies, differences between the paper reality and grassroots experiences of poor implementation and a lack of resources means that adopted policies often do not achieve intended outcomes. Because addressing climate change impacts involves cross-scale, crossboundary, and cross-sectoral issues, new policies are not enough. Vietnam will need to make structural and philosophical shifts to enable climate-related policies to achieve desired results.

One shift that could be made can be seen in Dannevig and Aall's (2015) argument that regional-scale governance can be an appropriate level to facilitate communication and coordination, particularly between local contextual knowledge and expert adaptation knowledge. Regional coordination in Vietnam, especially coordination of climate change in the Vietnamese Mekong Delta, remains academically underexplored. There is some research in Vietnamese academic journals but little information in international English language journals. There is broad agreement in the existing literature that coordination at the subnational regional level in the Vietnamese Mekong Delta is of high importance, particularly in the face of market pressures and the continuing international integration of Vietnam's economy, with the associated exchanges of culture, labor migration, and environmental challenges (Ho and Le 2012, Nguyen 2012, Tran et al. 2015). According to Nguyen (2012) the Vietnamese government has a legal framework that supports regional coordination including coordination regulations, coordinating groups, and management instruments such as plans and strategies. Tran et al. (2015) assessed climate change impacts and argued that actions focusing on the long term are urgently required, and that regional, inter-regional, and national level action and coordination are fundamental to sustainable development. Despite existing regulations and management instruments, Tran et al. (2015) identified the South West Steering Committee (SWSC) as the only regional governance mechanism in the delta. They proposed a specialized climate change coordination office be established under the authority of the SWSC, with funding from the central budget and international donors. This research furthers the work of Tran et al. (2015) by using the health sector as a case study to examine ways to improve collaborative cooperation across sectors, boundaries, and scales in the Vietnamese Mekong Delta. 
Table 2. Adaptation and health-related laws, processes, agreements, strategies, policies, and plans.

\begin{tabular}{|c|c|c|c|}
\hline Reference & Title & Year & Authority/Agreement \\
\hline $\begin{array}{l}\text { Internationally driven } \\
\text { (MONRE 2003) }\end{array}$ & Initial National Communication & Submitted 2003 & $\begin{array}{l}\text { United Nations Framework Convention } \\
\text { on Climate Change (UNFCCC) }\end{array}$ \\
\hline (MONRE 2010) & Second National Communication & Submitted 2010 & UNFCCC \\
\hline (MONRE 2014) & Initial Biennial Updated Report (IBUR) & Submitted 2014 & UNFCCC \\
\hline (GOV 2015a) & $\begin{array}{l}\text { Intended Nationally Determined Contribution } \\
\text { (INDC) }\end{array}$ & Submitted 2015 & UNFCCC \\
\hline \multicolumn{4}{|c|}{ National laws, processes, strategies, and plans } \\
\hline (GOV 2011) & National Climate Change Strategy (NCCS) & 2011 & Government of Vietnam \\
\hline (GOV 2008) & $\begin{array}{l}\text { National Target Program to Respond to Climate } \\
\text { Change (NTP-RCC) }\end{array}$ & 2008 & Government of Vietnam \\
\hline (GOV 2012) & $\begin{array}{l}\text { National Action Plan on Climate Change } \\
\text { (NAP-CC) }\end{array}$ & 2012 & Government of Vietnam \\
\hline (GOV 2002) & Budget Law & 2002 & Government of Vietnam \\
\hline (GOV 2015b) & Budget Law & 2015 & Government of Vietnam \\
\hline (GOV 2014) & National Socio-Economic Development Plan & 2014 & Government of Vietnam \\
\hline (MoH 2010) & $\begin{array}{l}\text { Ministry of Health Action Plan to Address } \\
\text { Climate Change }\end{array}$ & $2010-2015$ & The Ministry of Health \\
\hline N/A & $\begin{array}{l}\text { National Environmental Health Action Plan } \\
\text { (NEHAP) }\end{array}$ & $\begin{array}{c}\text { Rejected (by } \\
\text { parliament) } 2012 \\
\text { Rejected (by } \\
\text { Environment } \\
\text { Minister) } 2015\end{array}$ & $\begin{array}{l}\text { Regional Forum on Environmental } \\
\text { Health (RFEH) }\end{array}$ \\
\hline \multicolumn{4}{|c|}{ Regional process, strategies, and plans } \\
\hline (GOV 2016) & $\begin{array}{l}\text { Regulation for Pilot Coordination for Regional } \\
\text { Socio-economic Development in the Mekong } \\
\text { Delta }\end{array}$ & 2016 & Government of Vietnam \\
\hline (GOV and GOTN 2013) & $\begin{array}{l}\text { Mekong Delta Plan: Long-term Vision and } \\
\text { Strategy for a Safe, Prosperous and Sustainable } \\
\text { Delta }\end{array}$ & 2013 & $\begin{array}{l}\text { Government of Vietnam and } \\
\text { Government of the Netherlands }\end{array}$ \\
\hline \multicolumn{4}{|c|}{ Provincial level plans and strategies } \\
\hline (Dong Thap PPC 2011) & $\begin{array}{l}\text { Provincial Action Plans to Respond to Climate } \\
\text { Change for Dong Thap Province }\end{array}$ & 2011 & The People's Committee of Dong Thap \\
\hline (Kien Giang PPC 2013) & $\begin{array}{l}\text { Provincial Action Plans to Respond to Climate } \\
\text { Change for Kien Giang Province }\end{array}$ & 2013 & The People's Committee of Kien Giang \\
\hline (Can Tho PPC 2010) & $\begin{array}{l}\text { Provincial Action Plans to Respond to Climate } \\
\text { Change for Can Tho Province }\end{array}$ & 2010 & The People's Committee of Can Tho \\
\hline (Bac Lieu PPC 2012) & $\begin{array}{l}\text { Provincial Action Plans to Respond to Climate } \\
\text { Change for Bac Lieu Province }\end{array}$ & 2012 & The People's Committee of Bac Lieu \\
\hline (An Giang PPC 2010) & $\begin{array}{l}\text { Provincial Action Plans to Respond to Climate } \\
\text { Change for An Giang Province }\end{array}$ & 2010 & The People's Committee of An Giang \\
\hline (Ben Tre PPC 2011) & $\begin{array}{l}\text { Provincial Action Plans to Respond to Climate } \\
\text { Change for Ben Tre Province }\end{array}$ & 2011 & The People's Committee of Ben Tre \\
\hline (Ca Mau PPC 2012) & $\begin{array}{l}\text { Provincial Action Plans to Respond to Climate } \\
\text { Change for Ca Mau Province }\end{array}$ & 2012 & The People's Committee of Ca Mau \\
\hline (Soc Trang PPC 2011) & $\begin{array}{l}\text { Provincial Action Plans to Respond to Climate } \\
\text { Change for Soc Trang Province }\end{array}$ & 2011 & The People's Committee of Soc Trang \\
\hline (Tra Vinh PPC 2010) & $\begin{array}{l}\text { Provincial Action Plans to Respond to Climate } \\
\text { Change for Tra Vinh Province }\end{array}$ & 2010 & The People's Committee of Tra Vinh \\
\hline (Vinh Long PPC 2012) & $\begin{array}{l}\text { Provincial Action Plans to Respond to Climate } \\
\text { Change for Vinh Long Province }\end{array}$ & 2012 & The People's Committee of Vinh Long \\
\hline
\end{tabular}

\section{METHODS AND LIMITATIONS}

Using public health in the Vietnamese Mekong Delta as a focus area, this research examines the role that the three dimensions of coordination, outlined in Table 1, can and do play in supporting climate change adaptation. Although Vietnam has been proactive in policy development, its poor record of policy implementation (e.g., Tran 2016 argued that lack of understanding of adaptation measures on the part of provincial environmental and agricultural officials undermines climate change policy implementation) means that policy analysis alone does not provide a clear picture of the coordination of health sector adaptation to climate change. For this reason, the research presented in this paper uses data from in-depth semistructured interviews to guide and add depth to the policy analysis and to help highlight areas where there is a 
mismatch between on-the-ground reality and the paper-reality of policy frameworks. The analysis began with the coding of themes that emerged from the interviews. The policies were then examined in light of these themes.

To help mitigate any bias effects, the researchers interviewed officials from a variety of levels within government as well as from a variety of organizations working outside of government. To promote trust and encourage interviewees to openly share their insights, the researchers relied on personal introductions to meet interviewees. Beyond this, interviewees were advised that where they did not feel comfortable answering questions they were not obliged to answer, and were advised that all interviews would be treated as confidential and anonymous. Despite this, it was observed that junior staff within government agencies were more open than senior officials to discussion of problems and concerns that they saw. The researchers also interviewed recently retired directors of national-level government agencies, and these individuals were more willing to share their views and perspectives than currently employed senior officials. Officials at the provincial level and personnel from nongovernment and international organizations were generally quite open to discussion of both positive and negative aspects of climate change adaptation governance.

Interviews were conducted with environment and health ministry officials, as well as with personnel from nongovernment organizations (NGOs) and international organizations. The interviews were used to explore issues of adaptation coordination, in the context of Vietnam's adaptation policy framework, and particularly to get expert viewpoints on government policies. Fourteen interviews were conducted with officials in government offices, in both national and provincial positions across the health and environment ministries. In addition, 14 officials from nongovernment and international organizations were interviewed to further illuminate coordination issues relating to health and adaptation.

Interviews were conducted in English, and ranged from 24 to 81 minutes in length. An average interview length of 54 minutes was calculated by dividing the total number of interview minutes by the number of interviewees. Interview data was transcribed, and each transcript was read to identify themes. Data on themes common across interviews was collated manually. Collated data was then reviewed for subthemes and analyzed in the context of the policies, strategies, and plans that were reviewed. Each interviewee was ascribed a code that has been used in this paper to cite interviews. For example, data provided by interviewee number five is cited as (\#05).

The policy review included relevant national and provincial level strategies and plans, as well as international agreements through processes such as the UNFCCC. The policies, strategies, and plans reviewed are presented in Table 2.

The study had some limitations. Provincial and departmental climate change action plans are not publicly available, however the research team procured provincial action plans for 10 out of the 13 Mekong Delta provinces. Further research and analysis of departmental action plans would add depth to the knowledge of Vietnamese governance systems and their ability to deliver sustainable climate change adaptation actions, particularly in relation to cross-sectoral, cross-boundary, and cross-scale coordination.

Research methodologies do influence interpretation of data. In this case, the focus of systems theory on communication and control mechanisms and feedback loops and novel ways to alter these may have induced researchers to underplay obstacles and constraints associated with entrenched bureaucratic systems. Similarly, resilience thinking's focus on "changing to remain the same" could limit the ability of the researchers to see the extent to which bureaucratic systems can be resistant to change.

\section{RESULTS}

\section{International communications and commitments}

Vietnam has submitted two national communications to the UNFCCC (MONRE 2003, 2010). In its section on climate change impacts and adaptations, Vietnam's second national communication to the UNFCCC has a five and a half page subsection dealing with impacts on human health, with three of these pages on adaptation measures, including detail of time horizons for adaptations (MONRE 2010). Some adaptations are directly focused on the health sector, and the document also highlights links between health and other sectors such as water resources, the coastal zone, agriculture, and energy/transportation, thus highlighting the need for cross-sectoral coordination. Similarly, Vietnam's INDC highlights human health as a priority area in Vietnam's response to climate change. It also acknowledges that coordination between ministries and between localities is lacking in effectiveness (GOV 2015a). Despite the priority ascribed to the health sector in Vietnam's INDC and second national communication, the health ministry was not one of the 11 ministries cited as having contributed to Vietnam's Initial Biennial Updated Report to the UNFCCC (MONRE 2014), suggestive of the paper/reality divide.

\section{National policies and strategies}

The Vietnamese government has developed a number of national policies to support efforts to deal with climate change. In 2008 the NTP-RCC was published, followed by the National Climate Change Strategy (NCCS) in 2011 and the National Action Plan on Climate Change (NAP-CC) for the period 2012-2020 (GOV 2008, 2011, 2012). Along with Central Party Committee resolutions (e.g., Central Party Committee 2013), these documents identify human health as a priority area, in alignment with both the second national communication to the UNFCCC and Vietnam's INDC. These documents also reference coordination or collaboration among sectors and localities, but do not elaborate on what coordination and collaboration mean in practice.

The NTP-RCC provides the overarching framework for Vietnam's responses to climate change, setting out the directions for the development of both provincial level and sectoral adaptation action plans. It includes public health as a key area of concern and specifies that by 2015 "the mechanism for coordination among agencies responsible for climate change issues" will be perfected (GOV 2008, article III(4)(b)). Interviewees agreed that health-related impacts of climate change are cause for concern, noting increasing instances of floods, droughts, and typhoons, and associated food security issues (e.g., \#11, \#20). Although the prioritization of human health is 
reiterated in the NCCS as well as in the NAP-CC, specific actions and targets are vague, in line with MacLean's (2013) observation of paper-based realities resulting in vague policies. For example the list of projects in the NAP-CC gives the Ministry of Health $(\mathrm{MoH})$ responsibility for "upgrading" community healthcare systems in response to a changing climate, "strengthening" disease surveillance systems, and "ensuring" food hygiene and safety, in the period 2013-2015 (GOV 2012, article II (A) (49)), while implications of issues linked to climate change, such as land subsidence in the Mekong Delta, are not considered in relevant strategies (\#01). In accordance with NTP-RCC requirements, in 2010 the $\mathrm{MoH}$ published their climate change action plan for the period 2011-2015 (MoH 2010). This plan identifies climate change and infectious disease development as areas of particular concern. The plan has references to coordination across provincial boundaries, however these are vague and contradictory. The climate change health strategy for the period 2016-2020 is still awaiting approval (\#21). In 2015, the MoH did issue a health sector action plan to respond to natural disasters for the period 2015-2020, which provides measures for the health sector to deal with natural disasters by region including the Vietnamese Mekong Delta. Although there is an updated draft climate change strategy for health, interviewees expressed the view that the health ministry does not have a strong commitment to dealing with climate change, and that the health ministry is quite weak compared with other Vietnamese ministries (\#04, \#11, \#20). Lack of clear evidence of links between health outcomes and climate change was also perceived as constraining health sector adaptation (\#20, \#27).

Both the NTP-RCC and the NCCS required government ministries to develop their own climate change action plans. Both government and nongovernment interviewees stressed the importance of cooperation and coordination across sectors (e.g., \#19, \#20), however current coordination appears limited to functional cooperation. For example, the Ministry of Natural Resources and Environment (MONRE) and the Ministry of Planning and Investment (MPI) cooperate in a functional manner to screen climate change project proposals for technical suitability (a MONRE responsibility) before they are prioritized against other funding requests (an MPI responsibility), whereas collaborative cooperation between environment and health to achieve environmental health outcomes is lacking (\#07, \#19). Another example is that through the Regional Forum on Environment and Health, Vietnam has been encouraged to develop a National Environmental Health Action Plan (NEHAP; \#24). A MONRE vice-minister championed the original NEHAP, but this was rejected by Vietnam's Prime Minister in 2012. Subsequently the MONRE vice-minister retired and a revised NEHAP was rejected by the environment minister, who argued that $\mathrm{MoH}$ should take responsibility. More collaboration during development would have been more likely to bring out concerns about who should be responsible much earlier in the process. Government documents do refer to cross-sectoral coordination. For example the health sector action plan for natural disasters specifies that the $\mathrm{MoH}$ will coordinate regional programs with the participation of relevant ministries as well as provincial government bodies $(\mathrm{MoH} 2015)$. The importance of effective cross-sectoral coordination can be seen because of the related responsibilities of different agencies. For example, the
Ministry of Agriculture and Rural Development (MARD) is the lead agency for the supply of water in rural areas, as well as for environmental sanitation. The $\mathrm{MoH}$, by contrast, is the lead agency for promoting household sanitation and hygiene via the Health Environment Management Agency (HEMA), and the MONRE is responsible for climate change governance and integrated water resource management (World Bank and Water and Sanitation Program 2014).

\section{Regional level}

Within the Vietnamese Mekong Delta, cross-boundary coordination was seen by interviewees as key because of the interconnected hydrology of the provinces (\#01, \#04). In line with this, in 2013 Vietnam developed the Mekong Delta Master Plan to coordinate and review sustainable development in the Vietnamese Mekong Delta. The plan notes that for "future development and adaptation of the Mekong Delta" there should ideally be a legal entity that is "cross-sectoral in nature and capacity" and that would review "sectoral, departmental, provincial etc. plans" (GOV and GOTN 2013:73). The plan includes five references to human health. Subsequently, in 2014 the Vietnamese Government published the socioeconomic development plan for the Mekong Delta through 2020 (GOV 2014). This plan notes the importance of developing a regionalscale public health system, and designates Can Tho City as the centre for public health in the delta. Despite this, the MoH was not one of the nine ministries assigned as implementation agencies for this plan. Under the central communist party, the SWSC was established to coordinate actions across the Vietnamese Mekong Delta, and the Mekong Delta Master Plan gives the SWSC a coordination and monitoring role, as well as stating that the committee will assist ministries and provinces to implement the plan (GOV and GOTN 2013).

In April 2016 Prime Ministerial Decision No. 593/QD-TTg was published (GOV 2016). The decision included a regulation for Pilot Coordination for Regional Socio-economic Development in the Mekong Delta. Prior to its publication, international development partners supported its development (e.g., MBFP 2016), and in April 2016, 15 multilateral and bilateral development partners issued a joint statement supporting regional coordination in Vietnam, highlighting that, "[m]any important challenges for Viet Nam's development need to be addressed at a supra-provincial level" including, "[r]egional economic development, climate change adaptation, and regional infrastructure development" (Asian Development Bank et al. 2016:1). Despite this, the regulation only mentions climate change three times. Although the study of socioeconomics and socioeconomic development includes the health sector (e.g., Szirmai 2005), the only reference in the regulation that may relate to health is that the purpose includes to "improve livelihoods" and to "enhance the quality of life of local people" (GOV 2016, Article 2). The regulation gives MPI the lead role in coordinating socioeconomic development, however use of the term coordination appears to be limited to functional cooperation in pursuit of economic development. The pilot regulation gives the SWSC responsibility for collaborating with MPI on implementation of coordination activities and assisting with the final assessment and review of the pilot regulation. One possible reason for the choice of MPI over SWSC as lead is that Vietnam's budget laws of 2002 and 2015 exclude the regional level (GOV 
2002, 2015b), which would make it difficult for the central government to delegate responsibility to a regional level governance mechanism such as the SWSC.

\section{Provincial level}

The Mekong Delta includes 13 of Vietnam's 63 provinces. Under the NTP-RCC and NCCS requirements, the 13 Mekong provinces have each developed a Provincial Action Plan to Respond to Climate Change (PAP-RCC). Ten of the 13 Mekong Delta provincial action plans were reviewed, as detailed in Table 2. Of these 10 , nine included health-related actions in their detailed list of projects. Of these, the number of health-related projects ranged from $2-15 \%$ of the total projects, with proposed expenditures ranging from $0.003 \%$ (Kien Giang) to $5.38 \%$ (Bac Lieu) of total proposed expenditure (Bac Lieu PPC 2012, Kien Giang PPC 2013). Five of the 10 provinces included some consideration of coordination. For example, the PAP-RCC of each of Dong Thap and Bac Lieu provinces acknowledged the necessity of working with neighboring provinces to effectively respond to climate change impacts. Despite this, the lists of proposed projects in their action plans are provincial-scale projects that do not link with projects in other provinces (Dong Thap PPC 2011, Bac Lieu PPC 2012). The Ben Tre and Tra Vinh plans also included consideration of delta-wide, i.e., cross-boundary, coordination for coastal management and ecological protection, and the Soc Trang and Dong Thap plans mentioned both coordination within the province and delta-wide coordination as prerequisites to successful climate change adaptation (Tra Vinh PPC 2010, Ben Tre PPC 2011, Dong Thap PPC 2011, Soc Trang PPC 2011). The Bac Lieu plan also mentioned cross-sectoral coordination for search and rescue, however one interviewee described a climate change project with a focus on water-borne diseases in the delta that did not have representation from the Department of Health (DoH) because the Department of Agriculture and Rural Development (DARD) plays the key role in fresh water provision (\#23). Despite many of the provincial plans referring to coordination, it was an issue that concerned interviewees for four primary reasons: (i) funding for each province is isolated from other provinces, (ii) provinces do not have any authority to direct activities of other provinces, (iii) there are no formal mechanisms to support cross-boundary coordination between provinces, and (iv) coordination is generally viewed in Vietnam as the ability or authority to direct the activities of others (\#01, \#05, \#15, \#19, \#28).

The systems thinking philosophy on which this research was based highlighted a number of existing control mechanisms that limit collaborative coordination. For example, NGO personnel observed that coordination in Vietnamese public administration is interpreted as direction and control. Similarly, one civil servant commented on the inability of provinces to coordinate because none had the authority to tell other provinces what to do, and within provinces "DONRE [Department of Natural Resources and Environment] planners have no leverage over the planning and investment decisions of other agencies" (Nguyen et al. 2015:27). Indirect support for this view also came from comments of government personnel on the importance of mandates and division of roles, responsibilities, and authorities. As described, these divisions support functional cooperation but are less helpful in encouraging and supporting collaborative cooperation.

\section{DISCUSSION}

The purpose of this discussion section is twofold. First, it explores gaps in policy and policy implementation that were highlighted through our analysis of policies and interview data. Second, it builds on this exploration to suggest a possible solution to current gaps in collaborative cooperation for health sector adaptation to climate change in the Vietnamese Mekong Delta.

Coordinated governance processes are important for health sector adaptation to climate change in the Vietnamese Mekong Delta. For example, the provinces in the delta are connected to each other by the flow of the Mekong River and its various channels (\#01, $\# 05$ ), and these flows can facilitate the spread of water- and vector-borne diseases. Expected changing rainfall patterns will influence rates of transmission and disease spreads. This highlights the linkages across both provinces and sectors as well as the links with climate change. In addition to the geographic and sectoral coordination mechanisms, national government policies, strategies, and financing can all impact on the health sector and its ability to prepare for climate change impacts. This discussion section focuses on these three dimensions of coordination and to do so draws on policy analysis and interview data results from a range of scales, geographies, and sectors. Existing collaborative coordination gaps and constraints are identified, and one possible longer term solution to these is presented to stimulate further debate about coordination for health sector adaptation to climate change.

\section{Current coordination gaps and constraints}

There is a lack of coordination built into Vietnam's national legal framework. For example, the law on issuing of legal documents does not include any provisions that describe coordinating relationships between relevant bodies, and Vietnam does not have a "central agency to monitor the performance of [...] agencies in their enactment of laws and ordinances" (Thach 2014:74). Additionally, Thach (2014) noted that improved coordination between national assembly committees and government ministries in assessing future projects would improve the quality of laws and ordinances. Given the top-down approach to governance that is still dominant in Vietnam (Gainsborough et al. 2009, Fforde 2011, Benedikter 2016), it is not surprising that lack of coordination at the level of the national assembly is mirrored at the ministry level. Further, central government efforts to retain tight policy control (Christoplos et al. 2017) inevitably lead to a strong degree of micromanagement. This micromanagement can be seen in the view expressed by both those working within government and outside of government that coordination in Vietnam is the ability or authority to direct the actions of others (e.g., \#01, \#05,\#15). This focus on control and authority can be seen in Garschagen's (2015:613) observation that strategies to deal with floods in Can Tho City have not been developed because the cross-cutting nature of the problem means it "falls in between the compartmentalized responsibilities of the sectoral departments." The reliance on clear authority to act, combined with unclear coordination guidelines, increases the hurdles for improvements in all three coordination dimensions.

The Mekong Delta Master Plan highlights the need for an entity with cross-sectoral capabilities to oversee provincial and sectoral sustainable development plans (GOV and GOTN 2013). The plan follows on from central government concerns about provincial 
competition for economic development through foreign direct investment (FDI), which in the early 2000s led to over half of Vietnam's 63 provinces breaking central government investment policies in a "race to the bottom" (Vu et al. 2007:1). Despite the development of the master plan the Vietnamese government does not have an existing regional presence (Nguyen 2012, Tran et al. 2015), and so current regional governance mechanisms rely on steering committees, such as the SWSC, which is a communist party committee that does not have its own financial and human resources or decision-making authority in regard to regional linkages (Ho and Le 2012, Nguyen 2012). The master plan addresses this by tasking the SWSC to collaborate with MPI for implementation, however this raises cross-scale coordination issues that are not considered in the plan.

Although both the international level agreements and the national policies and strategies reviewed highlighted public health as a priority adaptation area, there are a number of key factors that inhibit and constrain health sector adaptation across the Vietnamese Mekong Delta. These factors are most visible at the provincial level. It is reasonable for the MARD, and consequently the DARD, to have responsibility for rural water supply. However, a lack of involvement of the $\mathrm{DoH}$ and the $\mathrm{MoH}$ in rural water supply, even in relation to projects focused on water-borne diseases (\#23), undermines Vietnam's ability to control these diseases, which have been identified as climate-sensitive because of the changing precipitation patterns that result from climate change. The lack of involvement of the health sector in areas that affect population health reflects the weakness of the health sector generally (\#04, \#11, \#20). Higher prioritization and resourcing (financial, human, regulations, and systems) of the health sector in the delta would support climate change adaptation efforts, because healthier people are better equipped to deal with the shocks and changes that a changing climate will bring (e.g., Smyle 2014). Water-borne disease control is both a cross-sectoral and a cross-boundary issue, because of the interconnected nature of the hydrology across the Vietnamese Mekong Delta (\#01, \#05), and because of links to other areas such as storm water management. Cross-sectoral coordination issues exist at the national level as well: collaborative coordination between Vietnam's health and environment ministries to develop the NEHAP would have avoided a ministerial rejection based on concerns about where responsibility for its development lay.

\section{One possible solution to regional coordination for health sector adaptation}

Better coordination across boundaries, scales, and sectors is closely linked to resilience thinking and the ability to modify practices and behaviors as the climate changes. Processes of collaborative action between sectors would mean that, for example, the DoH would work with the DARD to address issues around water-borne diseases. Processes supporting crossboundary collaboration would result in projects in PAP-RCCs designed to synergize with those of neighboring provinces. The existing Mekong Delta Master Plan is in line with this thinking with its acknowledgement of a need for cross-sectoral and crossboundary coordination (GOV and GOTN 2013). Despite this ideal, collaborative cooperation within the Vietnamese bureaucracy is difficult because of the importance placed on mandates, which promote functional cooperation (e.g., \#01, \#07, $\# 15$ ), and also because of its resistance to change (Benedikter
2016). The use of resilience thinking in this context could support government officials from different departments to work together and develop strong understandings of each other's priorities and perspectives. This may appear to blur the individual ministerial mandates, but would not impact on the core of the government ministries or organizations involved. The manner in which mandates are described by interviewees is also suggestive of sectoral systems that are separate from external influence, and although systems thinking promotes the idea of boundaries, these should be chosen with care. A choice of system boundaries that is in closer alignment with natural systems and the lives of people living in the Mekong Delta would better support health sector adaptation to climate change. The health sector, and hence public health, would be likely to be a prime beneficiary of a well-designed and implemented coordination mechanism. Making changes to established bureaucratic mechanisms will require significant time and energy, particularly because of deviations between reality as seen in government documents and on-the-ground reality (MacLean 2013). For this reason it is important that these concerns are debated and discussed including among national leaders and decision makers, who have to balance many priorities, and may be motivated by factors such as the economic benefits of better cross-sectoral, cross-boundary, and cross-scale coordination.

Tran et al. (2015) have discussed regional coordination issues, and suggested a specialized climate change coordination office under the SWSC to develop climate change policies specifically targeting the Vietnamese Mekong Delta. Interviewees also saw the SWSC as a possible solution to coordinating climate change responses (\#01, \#15, \#28), because existing weak regional linkage mechanisms combined with fragmented institutions inhibit the cross-sectoral and cross-boundary collaboration that could support health sector adaptation to climate change. Despite this, the SWSC would face some serious challenges in doing this. First, there would likely be significant opposition to proposals for SWSC to take on a role coordinating adaptation activities across the Vietnamese Mekong Delta from existing ministries such as MONRE and MARD, both of which have a large stake in climate change activities and associated finance. Second, the government aims to maintain a clear separation between the government and the communist party, which could make it difficult for the SWSC, as a communist party committee, to gain support to fill an official governing role (\#28). The third challenge links to control mechanisms, as considered in systems theory, because the SWSC does not have official authority over provincial authorities (\#01), and in a context where coordination is viewed synonymously with the ability to direct control, this would be a likely obstacle. The use of systems theory and resilience thinking promotes optimism about overcoming these obstacles, however moving from a rigid hierarchical system to a system based on collaborative coordination would require a shift in organizational culture and philosophy within the bureaucracy, which could take years or decades to achieve (for example Gainsborough et al. 2009 argued that the dominating centralist government is very resistant to change). A final obstacle is that the regional level in Vietnam is excluded from the national budgetary laws. However, even with limited funding, there could still be scope for the SWSC to facilitate collaboratively designed and implemented adaptation activities because coordination does not necessarily require direct 
project implementation (e.g., Robinson and Gilfillan 2017 argued that supra-national regional organizations may serve their member states more effectively through support of national efforts including capacity development, rather than through direct project implementation.).

Despite these numerous challenges, the SWSC has advantages that would support a role facilitating regional collaborative cooperation, including for the health sector. The SWSC was established as a coordinating agency, and is assigned coordination tasks for both the master plan for the delta and the pilot regulation for socioeconomic development. Its mandate would support a facilitation role (\#05), and it has already been involved in adaptation initiatives such as the running of a workshop on adaptation for vulnerable areas (TalkVietnam 2015). Connections between the 13 Provincial People's Committees (PPCs) could be directly facilitated by the SWSC (\#01), thereby supporting collaborative cooperation across the delta. This could also strengthen cross-sectoral collaboration because through the PPCs the SWSC has access to the provincial heads of line ministries. It could support cross-scale coordination because of its links downward into the PPCs and provincial line departments, as well as upward into the central government via the Deputy Prime Minister who is the head of the SWSC (Wyatt et al. 2012; also \#01). As such, the SWSC could be a conduit for information to the national government on existing and likely future conditions as well as recommendations on ways to achieve cross-boundary and cross-sectoral cobenefits with adaptation activities (Asian Development Bank et al. 2016; also \#01). As a regional organization with representation from across the delta it could balance the perspectives and interests of stakeholders from different places, scales, and sectors. This could be particularly beneficial for the health sector because, despite established links between human health and economic development (e.g., Gerdtham and Ekman 2005, Smith et al. 2014), the health sector in Vietnam has not been prioritized to the same extent as other sectors (\#04). A solution such as this would be in line with resilience thinking and systems theory because it is a novel approach that would require significant changes to the way governance is acted out in Vietnam without altering the core aspects of the communist state.

Despite the advantages that the SWSC could bring to a role facilitating collaborative coordination across sectors, provinces, and scales to aid climate change adaptation, including for the health sector, the challenges are substantial and it is unlikely that the SWSC would be called upon in this way in the near future. The authors of this paper acknowledge this, and make the recommendation as a way of stimulating debate and discussion about governance coordination issues in the Vietnamese Mekong Delta, and particularly to recommend that the debate is not confined to modifications that remain within existing norms and procedures.

\section{CONCLUSION}

The purpose of this paper was to examine coordination of climate change adaptation in the health sector in the Vietnamese Mekong Delta. It makes three primary contributions to the academic literature on health sector adaptation. First, it highlights the difference between existing functional cooperation between Vietnamese government sectors, and the collaborative cooperation that would more effectively support adaptation to climate change. Second, this paper adds to the scant literature on coordination of climate change adaptation in Vietnam, and is the first research into coordination to support adaptation in Vietnam's health sector. The weakness of the health sector in Vietnam highlights the imbalances that result from poor crossboundary, cross-sectoral, and cross-scale collaborative cooperation in the Vietnamese Mekong Delta. Increasing the level of understanding of, and commitment to, collaborative cooperation will be required to improve adaptation outcomes in the health sector. The third contribution of this research is to propose the SWSC as a suitable entity to facilitate collaborative cooperation for climate change adaptation in the Vietnamese Mekong Delta, including for the health sector. This proposed solution challenges current views on the role of this communist party committee, especially because the SWSC does not have authority delegated to it through decentralization mechanisms or parliamentary processes. In order for the SWSC to fill this role it would need to source funding either through the national government or international donors, or to make use of diplomatic and persuasive means to facilitate collaborative cooperation between provinces and sectors. This second option could be a significant challenge in the Vietnamese context, where coordination is viewed synonymously with authority to direct the actions of others.

This research has focused on health sector adaptation in the Vietnamese Mekong Delta, however the results will be useful for other sectors in Vietnam, such as the economic sector, which have faced interprovincial issues such as the race to the bottom. And because of Vietnam's lead on adaptation policy development in South East Asia, the research results should be of interest across the region.

Responses to this article can be read online at: http://www.ecologyandsociety.org/issues/responses. $\mathrm{php} / 9235$

\section{Acknowledgments:}

The authors acknowledge: The Fenner School of Environment and Society at The Australian National University and the Rotary Club of Hall for financial and material support to undertake fieldwork; the interviewees for their time and willingness to talk; A/Prof Jamie Pittock, Prof Lorraine Elliott, Adj Prof Howard Bamsey, and the reviewers for their constructive feedback on earlier drafts. The authors are responsible for any errors.

\section{LITERATURE CITED}

An Giang Provincial People's Committee (PPC). 2010. Action plan to respond to climate change of An Giang Province. The Provincial People's Committee of An Giang, An Giang, Vietnam.

Armitage, D. 2008. Governance and the commons in a multi-level world. International Journal of the Commons 2(1):7-32. http://dx. doi.org/10.18352/ijc. 28

Asian Development Bank, Agence Francaise de Developpement, Australian Department of Foreign Affairs and Trade, The Belgian 
Development Cooperation, Embassy of the Federal Republic of Germany in Hanoi, IFAD, Israel's Agency of International Development Cooperation, IUCN, Embassy of Japan in Hanoi, Korea International Cooperation Agency, Kingdom of the Netherlands, Swiss Department of Economic Affairs Education and Research, United Nations (Vietnam), USAID, and World Bank Group. 2016. Joint development partner statement on regional coordination in Viet Nam. Asian Development Bank, Agence Francaise de Developpement, Australian Department of Foreign Affairs and Trade, The Belgian Development Cooperation, Embassy of the Federal Republic of Germany in Hanoi, IFAD, Israel's Agency of International Development Cooperation, IUCN, Embassy of Japan in Hanoi, Korea International Cooperation Agency, Kingdom of the Netherlands, Swiss Department of Economic Affairs Education and Research, United Nations (Vietnam), USAID, World Bank Group. Hanoi, Vietnam. [online] URL: http://www.hanoi.diplo.de/contentblob/4776856/ Daten/6428250/160406_Joint_Statement_Konferenz_zu_regionaler Zusammenarbeit eng.pdf

Bac Lieu People's Committee (PPC). 2012. Action plan to respond to climate change of Bac Lieu Province. The Provincial People's Committee of Bac Lieu, Bac Lieu, Vietnam.

Baker, I., A. Peterson, G. Brown, and C. McAlpine. 2012. Local government response to the impacts of climate change: an evaluation of local climate adaptation plans. Landscape and Urban Planning 107(2):127-136. http://dx.doi.org/10.1016/j. landurbplan.2012.05.009

Ben Tre People's Committee (PPC). 2011. Action plan to respond to climate change of Ben Tre Province. The Provincial People's Committee of Ben Tre, Ben Tre, Vietnam.

Benedikter, S. 2014. The Vietnamese hydrocracy and the Mekong Delta: water resources development from state socialism to bureaucratic capitalism. Lit Verlag $\mathrm{GmBH} \&$ Co. Zurich, Switzerland.

Benedikter, S. 2016. Bureaucratisation and the state revisited: critical reflections on administrative reforms in post-renovation Vietnam. International Journal of Asia Pacific Studies 12(1):1-40.

Bierbaum, R., J. B. Smith, A. Lee, M. Blair, L. Carter, F. S. Chapin III, P. Fleming, S. Ruffo, M. Stults, S. McNeeley, E. Wasley, and L. Verduzco. 2013. A comprehensive review of climate adaptation in the United States: more than before, but less than needed. Mitigation and Adaptation Strategies for Global Change 18 (3):361-406. http://dx.doi.org/10.1007/s11027-012-9423-1

Ca Mau Provincial People's Committee (PPC). 2012. Action plan to respond to climate change of $\mathrm{Ca}$ Mau Province. The Provincial People's Committee of Ca Mau, Ca Mau, Vietnam.

Can Tho Provincial People's Committee (PPC). 2010. Action plan to respond to climate change of Can Tho Province. The Provincial People's Committee of Can Tho, Can Tho, Vietnam.

Cash, D. W., W. N. Adger, F. Berkes, P. Garden, L. Lebel, P. Olsson, L. Pritchard, and O. Young. 2006. Scale and cross-scale dynamics: governance and information in a multilevel world. Ecology and Society 11(2):8. http://dx.doi.org/10.5751/ES-01759-110208

Central Party Committee. 2013. Resolution No. 24INQ-TW of the 7th Conference of the 11th Central Party Committee: on proactive responses to climate change, enhanced natural resource management and environmental protection. Vietnam Communist Party, Hanoi, Vietnam. [online] URL: http://thuvienphapluat.vn/ van-ban/EN/Tai-nguyen-Moi-truong/Resolution-No-24-NQ-TWclimate-change-improvement-of-natural-resource-management/203397/ tieng-anh.aspx?tab=7

Christoplos, I., L. D. Ngoan, L. T. H. Sen, N. T. T. Huong, and L. S. Lindegaard. 2017. The evolving local social contract for managing climate and disaster risk in Vietnam. Disasters 41 (3):448-467. http://dx.doi.org/10.1111/disa.12215

Christopoulos, S., B. Horvath, and M. Kull. 2012. Advancing the governance of cross-sectoral policies for sustainable development: a metagovernance perspective. Public Administration and Development 32(3):305-323. http://dx.doi.org/10.1002/pad.1629

Costello, A., M. Maslin, H. Montgomery, A. M. Johnson, and P. Ekins. 2011. Global health and climate change: moving from denial and catastrophic fatalism to positive action. Philosophical Transactions of the Royal Society of London A: Mathematical, Physical and Engineering Sciences 369(1942):1866-1882. http:// dx.doi.org/10.1098/rsta.2011.0007

Dannevig, H., and C. Aall. 2015. The regional level as boundary organization? An analysis of climate change adaptation governance in Norway. Environmental Science \& Policy 54:168-175. http://dx.doi.org/10.1016/j.envsci.2015.07.001

Dong Thap Provincial People's Committee (PPC). 2011. Action plan to respond to climate change of Dong Thap Province. The Provincial People's Committee of Dong Thap, Dong Thap, Vietnam.

Esmark, A. 2011. Systems theory. Pages 91-105 in M. Bevir, editor. The SAGE handbook of governance. SAGE, Thousand Oaks, California, USA. http://dx.doi.org/10.4135/9781446200964.n7

Fforde, A. 2011. Contemporary Vietnam: political opportunities, conservative formal politics, and patterns of radical change. Asian Politics \& Policy 3(2):165-184. http://dx.doi.org/10.1111/ j.1943-0787.2011.01254.X

Folke, C., S. R. Carpenter, B. Walker, M. Scheffer, T. Chapin, and J. Rockström. 2010. Resilience thinking: integrating resilience, adaptability and transformability. Ecology and Society 15(4):20. http://dx.doi.org/10.5751/ES-03610-150420

Fritzen, S. A. 2006. Probing system limits: decentralization and local political accountability in Vietnam. Asia Pacific Journal of Public Administration 28(1):1-23. http://dx.doi.org/10.1080/23276665.2006.10779312

Gainsborough, M., D. N. Dinh, and T. T. Phuong. 2009. Corruption, public administration reform and development: challenges and opportunities as Viet Nam moves towards middleincome status. Pages 379-430 in J. Acuña-Alfaro, editor. Reforming public administration in Vietnam: current situation and recommendations. United Nations Development Programme Vietnam, Hanoi, Vietnam.

Galarraga, I., M. González-Eguino, and A. Markandya. 2009. The role of regions in climate change policy. Basque Centre for Climate Change (BC3), Bilbao, Spain. [online] URL: http://www. bc3research.org/working papers/downpubli 5.html 
Gamble, J. L., J. Balbus, M. Berger, K. Bouye, V. Campbell, K. Chief, K. Conlon, A. Crimmins, B. Flanagan, C. GonzalezMaddux, E. Hallisey, S. Hutchins, L. Jantarasami, S. Khoury, M. Kiefer, J. Kolling, K. Lynn, A. Manangan, M. McDonald, R. Morello-Frosch, M. H. Redsteer, P. Sheffield, K. Thigpen Tart, J. Watson, K. P. Whyte, and A. F. Wolkin. 2016. Populations of concern. Pages 247-286 in A. Crimmins, J. Balbus, J. L. Gamble, C. B. Beard, J. E. Bell, D. Dodgen, R. J. Eisen, N. Fann, M. D. Hawkins, S. C. Herring, L. Jantarasami, D. M. Mills, S. Saha, M. C. Sarofim, J. Trtanj, and L. Ziska, editors. The impacts of climate change on human health in the United States: a scientific assessment. U.S. Global Change Research Program, Washington, D.C., USA.

Garschagen, M. 2010. Crises prevention and climate change adaptation in the coupled social-ecological systems of the Mekong Delta, Vietnam: the need for rethinking concepts and policies. Pages 45-55 in X. Shen, T. E. Downing, and M. Hamza, editors. Tipping points in humanitarian crisis: from hot spots to hot systems. United Nations University Institute for Environment and Human Security (UNU-EHS). Bornheim, Germany.

Garschagen, M. 2015. Risky change? Vietnam's urban flood risk governance between climate dynamics and transformation. Pacific Affairs 88(3):599-621. http://dx.doi.org/10.5509/2015883599

Garschagen, M. 2016. Decentralizing urban disaster risk management in a centralized system? Agendas, actors and contentions in Vietnam. Habitat International 52:43-49. http://dx. doi.org/10.1016/j.habitatint.2015.08.030

Garschagen, M., and F. Kraas. 2011. Urban climate change adaptation in the context of transformation: lessons from Vietnam. Pages 131-139 in K. Otto-Zimmerman, editor. Resilient cities: cities and adaptation to climate change: Proceedings of the Global Forum 2010. Springer, Bonn, Germany. http://dx.doi. org/10.1007/978-94-007-0785-6 13

Gerdtham, U.-G., and B. Ekman. 2005. Investing in health for economic development in Vietnam: report on opportunities and constraints for a national macroeconomics and health program. World Health Organization, Geneva, Switzerland. [online] URL: http://www.who.int/macrohealth/action/CMH Vietnam Final.pdf

Government of Vietnam (GOV). 2002. Law No. 01/2002/QH11 on state budget. Government of Vietnam, Hanoi, Vietnam. [online] URL: http://www.moj.gov.vn/vbpq/lists/vn $\% 20 \mathrm{bn} \%$

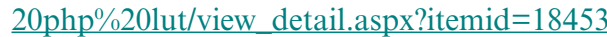

Government of Vietnam(GOV). 2008. Prime Ministerial Decision No. 158/2008/QD-TTg: on approval of the national target program to respond to climate change. Government of Vietnam, Hanoi, Vietnam. [online] URL: http://www.noccop.org.vn/Data/vbpq/ Airvariable ldoc 49enDecision $\% 20158 \% 20$ on $\% 20$ approval $\% 20$ of $\%$ 20NTP.pdf

Government of Vietnam(GOV). 2011. Prime Ministerial Decision 2139/QĐ-TTg: on approval of the national climate change strategy. Government of Vietnam, Hanoi, Vietnam. [online] URL: http:// chinhphu.vn/portal/page/portal/English/strategies/strategiesdetails? category $I d=30 \&$ article $I d=10051283$

Government of Vietnam(GOV). 2012. Prime Ministerial Decision No.: 1474/QD-TTg: on approval of the national action plan on climate change (2012 - 2020). Government of Vietnam, Hanoi, Vietnam. [online] URL: http://www.luatvn.net/Filedownload/135123/145653/en 1474 qd ttg.doc

Government of Vietnam(GOV). 2014. Prime Ministerial Decision No. 245/QD-TTg: on approval of the master plan on socioeconomic development of the Mekong Delta key economic region through 2020, with orientations toward 2030. Government of Vietnam. Hanoi, Vietnam. [online] URL: https://luatminhkhue. vn/en/decision/decision-no-245-qd-ttg-dated-february-12--2014-ofthe-prime-minister-approving-the-master-plan-on-socio-economicdevelopment-of-the-mekong-delta-key-economic-region-through-2020-with-orientations-toward-2030.aspx

Government of Vietnam (GOV). 2015a. Intended nationally determined contribution of Vietnam. Government of Vietnam, Hanoi, Vietnam. [online] URL: http://www4.unfccc.int/ submissions/INDC/Published \%20Documents/Viet $\% 20 \mathrm{Nam} / 1 /$ VIETNAM'S\%20INDC.pdf

Government of Vietnam (GOV). 2015b. Law No. 83/2015/QH13 on state budget. Government of Vietnam, Hanoi, Vietnam. [online] URL: http://vst.mof.gov.vn/webcenter/portal/kbnn/r/o/ tpcp/cces/cces chitiet?dDocName $=$ MOF148201\& afrLoop $=22$ 021069113878264\#! $\% 40 \% 40 \% 3 \mathrm{~F}$ afrLoop $\% 3 \mathrm{D} 22021069113878264 \%$ 26dDocName \%3DMOF148201\%26 adf.ctrl-state\%3Dnpowgd7yq 9

Government of Vietnam(GOV). 2016. Prime Ministerial Decision No. 593/QD-TTg: on approval of the regulation on pilot coordination for regional socio-economic development in the Mekong Delta 2016-2020. Government of Vietnam, Hanoi, Vietnam.

Government of Vietnam and Government of The Netherlands (GOV and GOTN). 2013. Mekong Delta plan: long-term vision and strategy for a safe, prosperous and sustainable delta. Government of Vietnam, Hanoi, Vietnam and Government of the Netherlands, Deltares, Netherlands. [online] URL: https:// www.wageningenur.n1/upload $\mathrm{mm} / 2 / \mathrm{c} / 3 / \mathrm{b} 5 f 2 \mathrm{e} 669-\mathrm{cb} 48-4 \mathrm{ed} 7$ afb6-682f5216fe7d mekong.pdf

Haines-Young, R., and M. Potschin. 2008. England's terrestrial ecosystem services and the rationale for an ecosystem approach. DEFRA Overview Report Project Code NR0107. University of Nottingham, Nottingham, UK. [online] URL: https://www. nottingham.ac.uk/cem/pdf/NR107 FTR 080108.pdf

Hansson, E. 2003. Authoritarian governance and labour: the VGCL and the party-state in economic renovation. Pages 153-184 in B. J. T. Kerkvliet, R. H. Heng, and D. W. Koh, editors. Getting organized in Vietnam: moving in and around the socialist sate. Institute of Southeast Asian Studies, Singapore.

Ho, K. M., and M. N. D. Le. 2012. Liên kết kinh tế vùng từ lý thuyết đến thực tiễn. Kỷ yếu Diễn đàn Kinh tế (mùa Thu 2012):444-455.

Huang, C., P. Vaneckova, X. Wang, G. FitzGerald, Y. Guo, and S. Tong. 2011. Constraints and barriers to public health adaptation to climate change: a review of the literature. American Journal of Preventive Medicine 40(2):183-190. http://dx.doi. org/10.1016/j.amepre.2010.10.025

Intergovernmental Panel on Climate Change (IPCC). $2014 b$. Annex II: Glossary. K. J. Mach, S. Planton, and C. von Stechow, 
editors. Pages 117-130 in Core Writing Team, R. K. Pachauri, and L. A. Meyer, editors. Climate change 2014: synthesis report. Contribution of Working Groups I, II and III to the Fifth Assessment Report of the Intergovernmental Panel on Climate Change. IPCC, Geneva, Switzerland.

Intergovernmental Panel on Climate Change (IPCC). 2014a. Climate change 2014: synthesis Report. Contribution of Working Groups I, II and III to the Fifth Assessment Report of the Intergovernmental Panel on Climate Change. Core Writing Team, R. K. Pachauri and L. A. Meyer, editors. IPCC, Geneva, Switzerland.

Irvin, G. 1995. Vietnam: assessing the achievements of Doi Moi. Journal of Development Studies 31(5):725-750. http://dx.doi. org/10.1080/00220389508422387

Kien Giang Provincial People's Committee (PPC). 2013. Action plan to respond to climate change of Kien Giang Province. The Provincial People's Committee of Kien Giang, Kien Giang, Vietnam.

Lesnikowski, A., J. D. Ford, L. Berrang-Ford, M. Barrera, P. Berry, J. Henderson, and S. J. Heymann. 2013. National-level factors affecting planned, public adaptation to health impacts of climate change. Global Environmental Change 23(5):1153-1163. http://dx.doi.org/10.1016/j.gloenvcha.2013.04.008

Mackay, P., and M. Russell. 2011. Climate change vulnerability \& risk assessment study for Ca Mau and Kien Giang Provinces, Vietnam. Asian Development Bank, Melbourne, Australia. [online] URL: http://www.adb.org/sites/default/files/projectdocument/73153/43295-012-vie-tacr-03-0.pdf

MacLean, K. 2013. The government of mistrust: illegibility and bureaucratic power in socialist Vietnam. University of Wisconsin Press, Madison, Wisconsin, USA.

Management Board for Forestry Products (MBFP). 2016. Gradually finalizing the Pilot Mechanism on regional coordination of cooperation in socio-economic development for the Mekong Delta, 2016-2020. MBFP, Ha Noi, Vietnam. [online] URL: http:// daln.gov.vn/en/ac130a909/gradually-finalizing-the-pilot-mechanismon-regional-coordination-of-cooperation-in-socio-economic-developmentfor-the-mekong-delta-2016-2020.html

Marmot, M. 2007. Achieving health equity: from root causes to fair outcomes. Lancet 370(9593):1153-1163. http://dx.doi. org/10.1016/S0140-6736(07)61385-3

McElwee, P. 2010. The social dimensions of adaptation to climate change in Vietnam. Development and Climate Change Discussion Paper no. 17, The World Bank, Washington, D.C., USA. [online] URL: http://www-wds.worldbank.org/external/default/ WDSContentServer/WDSP/IB/2011/01/11/00035616120110111012856/ Rendered/PDF/589030NWP0EACC10Box353823B01public1.pdf

McMichael, A. J., D. H. Campbell-Lendrum, C. F. Corvalán, K. L. Ebi, A. K. Githeko, J. D. Scheraga, and A. Woodward, editors. 2003. Climate change and human health: risks and responses. The World Health Organization, Geneva, Switzerland.

Ministry of Health (MoH). 2010. Ministerial Decision No. 3557 I $Q Đ-B Y T$ : on approval of action plan responses to climate change in health sector (2011-2015). Ministry of Health, Hanoi, Vietnam.
Ministry of Health (MoH). 2015. Ministerial Decision No. 646/ $Q Ð-B Y T$ : on approval of action plan in response to natural disaster of health sector period 2015-2020. Ministry of Health, Hanoi, Vietnam.

Ministry of Natural Resources and Environment (MONRE). 2003. Viet Nam: initial national communication under the United Nations Framework Convention on Climate Change. Government of Vietnam, Hanoi, Vietnam. [online] URL: http://unfccc.int/ resource/docs/natc/vnmnc01.pdf

Ministry of Natural Resources and Environment (MONRE). 2010. Vietnam's second national communication to the United Nations Framework Convention on Climate Change. Government of Vietnam, Hanoi, Vietnam. [online] URL: http://unfccc.int/ resource/docs/natc/vnmnc02.pdf

Ministry of Natural Resources and Environment (MONRE). 2014. The biennial updated report of Vietnam to the United Nations Framework Convention on Climate Change. Government of Vietnam, Hanoi, Vietnam. [online] URL: http://unfccc.int/ resource/docs/natc/vnmbur1.pdf

Nguyen, P. N., T. T. T. Tran, S. Tyler, Q. A. Nguyen, T. S. Bach, N. H. Nguyen, K. Pham, and T. H. Dang. 2015. Local planning for climate adaptation: Vietnam's experience. The Rockefeller Foundation, the Asian Cities Climate Change Resilience Network, and the International Institute for Environment and Development, London, UK. [online] URL: http://pubs.iied.org/ pdfs/10741IIED.pdf

Nguyen, V. H. 2012. Liên kết vùng từ lý thuyết đến thực tiễ?n. Kỷ yếu Diê̂̀n đàn Kinh tế (mùa Thu 2012):418-443.

Parkes, M. W., K. E. Morrison, M. J. Bunch, L. K. Hallström, R. C. Neudoerffer, H. D. Venema, and D. Waltner-Toews. 2010. Towards integrated governance for water, health and socialecological systems: the watershed governance prism. Global Environmental Change 20(4):693-704. http://dx.doi.org/10.1016/ j.gloenvcha.2010.06.001

Phung, D., C. Huang, S. Rutherford, C. Chu, X. Wang, M. Nguyen, N. H. Nguyen, C. Do Manh, and T. H. Nguyen. 2015. Association between climate factors and diarrhoea in a Mekong Delta area. International Journal of Biometeorology 59 (9):1321-1331. http://dx.doi.org/10.1007/s00484-014-0942-1

Porter, J. J., S. Dessai, and E. L. Tompkins. 2014. What do we know about UK household adaptation to climate change? A systematic review. Climatic Change 127(2):371-379. http://dx.doi. org/10.1007/s10584-014-1252-7

Rasul, G. 2014. Food, water, and energy security in South Asia: a nexus perspective from the Hindu Kush Himalayan region. Environmental Science \& Policy 39:35-48. http://dx.doi. org/10.1016/j.envsci.2014.01.010

Robinson, S.-A., and D. Gilfillan. 2017. Regional organisations and climate change adaptation in small island developing states. Regional Environmental Change 17(4):989-1004. http://dx.doi. org/10.1007/s10113-016-0991-6

Smith, K. R., A. Woodward, D. Campbell-Lendrum, D. Chadee, Y. Honda, Q. Liu, J. M. Olwoch, B. Revich, and R. Sauerborn. 2014. Human health: impacts, adaptation and co-benefits. Pages 709-754 in C. B. Field, V. R. Barros, D. J. Dokken, K. J. Mach, 
M. D. Mastrandrea, T. E. Bilir, M. Chatterjee, K. L. Ebi, Y. O. Estrada, R. C. Genova, B. Girma, E. S. Kissel, A. N. Levy, S. MacCracken, P. R. Mastrandrea, and L. L. White, editors. Climate change 2014: impacts, adaptation, and vulnerability. Part A: Global and Sectoral Aspects. Contribution of Working Group II to the Fifth Assessment Report of the Intergovernmental Panel on Climate Change. Cambridge University Press, Cambridge, UK.

Smyle, J. 2014. Comprehensive environment and climate change assessment in Viet Nam. International Fund for Agricultural Development, Rome, Italy. [online] URL: https://www.ifad.org/ documents/10180/bc978d37-0907-4fef-acf0-fddbc9040011

Snover, A., L. Whitely Binder, J. Lopez, E. Willmott, J. Kay, D. Howell, and J. Simmonds. 2007. Preparing for climate change: a guidebook for local, regional, and state governments. Center for Science in the Earth System, University of Washington, Seattle, Washington, USA and ICLEI - Local Governments for Sustainability, Bonn, Germany. [online] URL: http://www.cses. washington.edu/db/pdf/snoveretalgb574.pdf

Soc Trang Provincial People's Committee (PPC). 2011. Action plan to respond to climate change of Soc Trang Province. The Provincial People's Committee of Ca Mau, Soc Trang, Vietnam.

Szirmai, A. 2005. The dynamics of socio-economic development: an introduction. Cambridge University Press, Cambridge, UK. http://dx.doi.org/10.1017/CBO9780511817342

Tai, H.-S. 2015. Cross-scale and cross-level dynamics: governance and capacity for resilience in a social-ecological system in Taiwan. Sustainability 7(2):2045-2065. http://dx.doi.org/10.3390/su7022045

Termeer, C. J. A. M., A. Dewulf, and M. van Lieshout. 2010. Disentangling scale approaches in governance research: comparing monocentric, multilevel, and adaptive governance. Ecology and Society 15(4):29. http://dx.doi.org/10.5751/ ES-03798-150429

Thach, P. N. 2014. Vietnam's national assembly's institutionalization and transformed functions. Pages 64-83 in Z. Yongnian, L. L. Fook, and W. Hofmeister, editors. Parliaments in Asia: institution building and political development. Routledge, Abingdon, UK.

Thayer, C. A. 1995. Mono-organizational socialism and the state. Pages 39-64 in B. Kerkvliet and D. J. Porter, editors. Vietnam's rural transformation. Institute of Southeast Asian Studies, Singapore.

Tra Vinh Provincial People's Committee (PPC). 2010. Action plan to respond to climate change of Tra Vinh Province. The Provincial People's Committee of Tra Vinh, Tra Vinh, Vietnam.

Tran, H. H., S. T. Nguyen, and H. N. Ha. 2015. Liên kết vùng trong ứng phó với biển đổi khí hậu ở Việt Nam (Qua nghiên cứu trường hợp đồng bằng sông Cửu Long). Tạp chí Nghiên cứu Địa lý nhân văn 1(8):17-24.

Tran, V. S. 2016. Towards successful implementation of Vietnamese national government climate change policy at the provincial and local farmer level. Southern Cross University, Lismore, Australia. [online] URL: http://epubs.scu.edu.au/cgi/viewcontent.cgi? article $=1493 \&$ context $=$ theses
Truong, T. H. 2011. Một số suy nghĩ về liên kết vùng đồng bằng sông cửu long và $\mathrm{Tp}$ Hồ Chí Minh trong chiến lược phát triển kinh tế. Tạp chí Phát triển Nguồn nhân lực. 5(26):40-46.

United Cities and Local Governments. 2009. Decentralization and local democracy in the world. United Cities and Local Governments, Paris, France. [online] URL: http://www. citiesalliance.org/sites/citiesalliance.org/files/CA_Docs/resources/ UCLG DecentralizationandLocalDemocracy.pdf http://dx.doi. org/10.1596/978-0-8213-7734-5

United Nations Development Programme (UNDP). 2007. UNDP Strategic Plan (2008-2011)- accelerating global progress on human development. UNDP, Geneva, Switzerland. [online] URL: https://www.undp-aap.org/resources/projects/undp-strategicplan-2008-2011-accelerating-global-progress-human-development

U.S. Forest Service (USFS). 2011. Climate change in Vietnam assessment of issues and options for USAID funding. USFS and USAID, Hanoi, Vietnam. [online] URL: https://www.usaid.gov/ sites/default/files/documents/1861/vietnam_climate change final2011. pdf

TalkVietnam. 2015. 6.3 million people in Mekong Delta are at risk affected by climate change. TalkVietnam, 26 November. [online] URL: https://www.talkvietnam.com/2015/11/6-3-millionpeople-in-mekong-delta-are-at-risk-affected-by-climate-change/

Vinh Long Provincial People's Committee (PPC). 2012. Action plan to respond to climate change of Vinh Long Province. The Provincial People's Committee of Vinh Long, Vinh Long, Vietnam.

$\mathrm{Vu}, \mathrm{T}$. T. A. 2012. Decentralization of economic management in Vietnam from institutional perspectives. Fulbright Economics Teaching Program, Ho Chi Minh City, Vietnam. [online] URL: http://www.fetp.edu.vn/cache/Decentralization $\% 20$ of $\% 20$ Economic $\%$ 20Management $\% 20 \mathrm{in} \% 20$ Vietnam-2013-02-21-18562504.pdf

Vu, T. T. A., V. T. Li, and T. T. Vo. 2007. Provincial extralegal investment incentives in the context of decentralization in Viet Nam: mutually beneficial or a race to the bottom? United Nations Development Programme - Vietnam, Hanoi, Vietnam. [online] URL: http://www.undp.org/content/dam/vietnam/docs/ Publications/9716 071205 provincentives.pdf

World Bank. 2015. Fiscal decentralization review in Vietnam: making the whole greater than the sum of the parts: a review of fiscal decentralization in Vietnam: summary report. The World Bank Group, Washington, D.C., USA. [online] URL: http:// documents.worldbank.org/curated/en/2016/03/26012370/makingwhole-greater-sum-parts-review-fiscal-decentralization-vietnam

World Bank and Water and Sanitation Program. 2014. Water supply and sanitation in Vietnam: turning finance into services for the future. International Bank for Reconstruction and Development/The World Bank, Washington, D.C., USA. [online] URL: https://www.wsp.org/sites/wsp.org/files/publications/WSPVietnam-WSS-Turning-Finance-into-Service-for-the-Future.pdf

World Health Organization (WHO). 2015. Climate change and health in the Western Pacific region: synthesis of evidence, profiles of selected countries and policy direction. WHO, Geneva, Switzerland. [online] URL: http://iris.wpro.who.int/handle/10665.1/12401 
Wyatt, A. B., T. P. T. Nguyen, and P. G. Tang. 2012. Viet Nam situation analysis. International Union for the Conservation of Nature, Gland, Switzerland. [online] URL: https://www.iucn.org/ sites/dev/files/import/downloads/bcr_viet_nam_situation_analysis final 1 1.pdf

Yusuf, A. A., and H. Francisco. 2009. Climate change vulnerability mapping for Southeast Asia. Economy and Environment Program for Southeast Asia, Singapore. [online] URL: http://itpibhopal. com/resource/12.pdf 